THE YALE CHILD STUDY CENTER MONOGRAPH SERIES ON CHILD PSYCHIATRY, CHILD DEVELOPMENT, AND SOCIAL POLICY 
The Yale Child Study Center monograph series on Child Psychiatry, Child Development, and Social Policy is published in association with Yale University Press. The series is a forum for the discussion of major scientific, clinical, and policy issues relating to children and families. 


\title{
Children in Jeopardy
}

CAN WE BREAK THE CYCLE OF POVERTY?

\author{
Irving B. Harris
}

THE YALE CHILD STUDY CENTER NEW HAVEN DISTRIBUTED BY YALE UNIVERSITY PRESS 
The excerpt "It Begins at Birth" in chapter 7 is copyrighted by the Chicago Tribune, all rights reserved, and is used with permission.

The excerpt from Unfair Shares in chapter 7 is reprinted by permission of Richard G. Wilkinson, Trafford Centre for Medical Research, University of Sussex, and the Centre for Health and Society, University College London.

The excerpt in chapter 7 from Keith Bradsher's article, "Low Ranking for Poor American Children," and figure 7-3, "The Gap between Rich and Poor Children," originally appeared in the New York Times on 14 August 1995 and I September 1995, respectively, and are reprinted with permission by The New York Times Company, copyright $\odot$ I995.

Library of Congress Cataloging-in-Publication Data

Harris, Irving B. (Irving Brooks), I910-

Children in jeopardy : can we break the cycle of poverty? / Irving B. Harris.

p. cm. - (The Yale Child Study Center monograph series on child psychiatry, child development, and social policy : vol I)

Includes bibliographical references and index.

ISBN 0-300-06892-I (cloth : acid-free paper)

I. Child welfare-United States. 2. Socially handicapped children-Services for-United

States. 3. Poor children-Services for-United States. 4. Teenage pregnancy-United

States-Prevention. I. Title. II. Series.

HV74I.H338 1996

$362.7^{\circ} 0973-\mathrm{dc} 20$

Copyright $\odot 1996$ by Irving Brooks Harris.

All rights reserved.

This book may not be reproduced, in whole or in part, including illustrations, in any form (beyond that copying permitted by Sections 107 and 108 of the U.S. Copyright Law and except by reviewers for the public press), without written permission from the publishers.

\section{Designed by Thos. Whitridge}

Set in Monotype Bembo by Ink, Inc. of New York City

Printed in the United States of America

A catalogue record for this book is available from the British Library.

The paper in this book meets the guidelines for permanence and durability of the Committee on Production Guidelines for Book Longevity of the Council on Library Resources.

ISBN $0-300-06892-1 \mathrm{CI}$ 
First, to my wife, Joan Harris, and to my children - Roxanne Frank, Virginia Polsky, William Harris, and his wife, Robie Harris-who along with Maria Piers have taught me about the enormous importance of very early childhood development.

Second, to our progeny in the hope that their world will be more civilized and more livable than it is today or promises to become.

Third, to the many federal, state, county, and city legislators and other elected officials I have known: decent, intelligent men and women who really try to help make our world a better place in which to live and raise our children with opportunities for them to grow, learn, and continue to grow. 
No American-white or black-can escape the consequences of the continuing social and economic decay of our major cities. Only a commitment to national action on an unprecedented scale can shape a future compatible with the historic ideals of American society.

-Kerner Commission report, 1968 